\title{
A Critical Analysis of Bio-Hydrocarbon Production in Bacteria: Current Challenges and Future Directions
}

\author{
Ziaur Rahman ${ }^{1, * \mathbb{C}}$, Javed Nawab ${ }^{2}$, Bong Hyun Sung ${ }^{3}$ and Sun Chang Kim ${ }^{4, *}$ \\ 1 Department of Microbiology, Abdul Wali Khan University Mardan, Mardan 23200, Pakistan \\ 2 Department of Environmental Sciences, Abdul Wali Khan University Mardan, Mardan 23200, Pakistan; \\ javednawab11@yahoo.com \\ 3 Cell Factory Research Center, Korea Research Institute of Bioscience and Biotechnology, Daejeon 34141, \\ Korea; bhsung@kribb.re.kr \\ 4 Department of Biological Sciences, Korea Advanced Institute of Science and Technology, \\ Daejeon 34141, Korea \\ * Correspondence: ziamicrobiologist@gmail.com (Z.R.); sunkim@kaist.ac.kr (S.C.K.); \\ Tel.: +92-340-901-2316 (Z.R.); +82-42-350-2619 (S.C.K.)
}

Received: 10 September 2018; Accepted: 3 October 2018; Published: 6 October 2018

check for updates

\begin{abstract}
As global fossil reserves are abruptly diminishing, there is a great need for bioenergy. Renewable and sustainable bioenergy products such as biofuels could fulfill the global energy demand, while minimizing global warming. Next-generation biofuels produced by engineered microorganisms are economical and do not rely on edible resources. The ideal biofuels are alcohols and $n$-alkanes, as they mimic the molecules in fossil fuels and possess high energy densities. Alcohols and $n$-alkane hydrocarbons $\left(C_{2}\right.$ to $\left.C_{18}\right)$ have been produced using engineered microorganisms. However, it is difficult to optimize the complex metabolic networks in engineered microorganisms to obtain these valuable bio-hydrocarbons in high yields. Metabolic engineering results in drastic and adverse cellular changes that minimize production yield in microbes. Here, we provide an overview of the progress in next-generation biofuel (alcohols and $n$-alkanes) production in various engineered microorganisms and discuss the latest tools for strain development that improve biofuel production.
\end{abstract}

Keywords: microbial biofuel; metabolic engineering; alkanes; alcohols

\section{Introduction}

The global scarcity and predicted depletion of fossil fuel reserves is a threat to future energy demand [1-3]. Excess consumption of transportation fuel leads to ever-increasing global warming [1,4]. There is an urgent need to replace the current fossil fuel technology with renewable, sustainable, and environmentally friendly alternatives [5,6]. Biofuels are considered sustainable if they are produced from biomass through biological or non-biological methods. The ideal biofuels are bio-hydrocarbons and these have been suggested as replacements for fossil fuels. Bio-hydrocarbons produced in bacteria, such as alcohols $\left(C_{2}-C_{18}\right)$ and $n$-alkanes $\left(C_{10}-C_{20}\right)$, are of great importance [7-9]. These bio-hydrocarbons have advantages over fossil fuels, as they possess higher energy densities and emit fewer toxic chemicals into the environment $[10,11]$. These ready-to-use bio-hydrocarbons do not require the replacement of existing engines and are compatible with current technologies [12]. The current methods used for production of these biofuels are non-economical and are based on the conversion of plant and vegetable oil using the Fischer-Tropsch method $[13,14]$. The genetically engineered microorganisms could utilize cheaper raw materials such as cellulosic sugars and carbon dioxide to produce bio-hydrocarbons more economically.

Bio-hydrocarbons (alcohols and $n$-alkanes) are produced in engineered bacteria by modifying their central metabolism, including glycolytic, tricarboxylic, and fatty acid pathways (Figure 1). The current 
production yield of bio-hydrocarbons from modified bacteria is far below commercial scale due to the challenges of metabolic engineering. Current challenges include cellular toxicity, growth retardation, cofactor exhaustion and metabolic pathway imbalance. In this paper, the metabolic engineering of bacteria for bio-hydrocarbon production is reviewed. In addition, we discuss current problems and challenges in strain optimization for bio-hydrocarbon production and provide future directions for this technology.

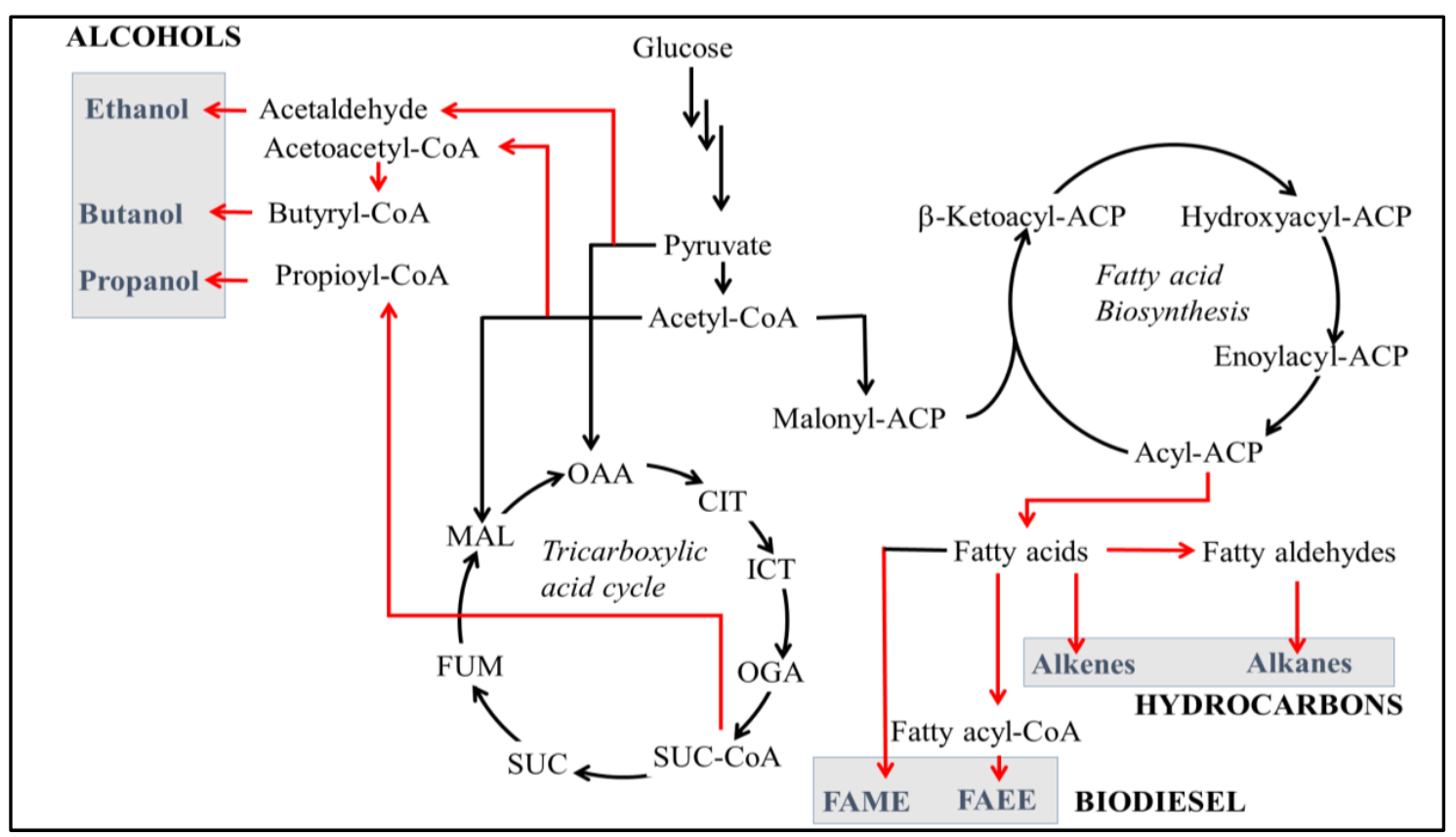

Figure 1. Metabolic pathways of short- and medium-chain alcohols and hydrocarbon production in an engineered bacterial cell. Glucose is metabolized to acetyl-CoA, a precursor of the tricarboxylic acid (TCA) cycle and fatty acid biosynthesis pathways. Short-chain alcohols (ethanol, propanol, butanol) are produced from acetyl-CoA and TCA. Fatty alcohols, fatty acid ethyl esters and $n$-alkanes are produced by utilizing fatty acyl-ACPs of the fatty acid machinery. The native pathways are shown in black, while heterologous pathways are shown in red. CoA: Coenzyme A; ACP: Acyl Carrier Protein; OAA: Oxalo Acetic Acid; CIT: Citrate; ICT: Iso Citrate; OGA: Oxo Glutaric Acid; SUC: Succinic Acid; FUM: Fumaric Acid; MAL: Malic Acid; FAME: Fatty Acid Methyl Ester; FAEE: Fatty Acid Ethyl Ester.

\section{Engineering Metabolic Pathways for Hydrocarbon Production in Bacteria}

Initial work on engineering microbes for biofuel production involved introducing the ethanol-producing pathway from Zymomonas mobilis into Escherichia coli [15]. The progress of most biofuels produced this way is discussed in detail in previous reviews [16-18]. In this section, we present an overview of alcohol and $n$-alkane biofuels produced by engineered microorganisms.

\subsection{Alcohols Production in Bacteria}

Next-generation alcohols are a group of compounds used in chemical industries and as transportation biofuels $[19,20]$. They can be grouped into short, medium, and long-chain alcohols, ranging from $C_{2}$ to $C_{6}, C_{6}$ to $C_{12}$, and $C_{12}$ to $C_{18}$ chain lengths, respectively [21-23]. They can be used as $100 \%$ solutions or blended with petroleum. Custom alcohols are currently produced by distillation during petroleum processing or chemically from fatty acids, which makes their production unviable in the long run. The sustainable approach to their production is to use fermenters, utilizing microorganisms that can easily convert cellulosic material into ready-to-use biofuels. Ethanol is a renewable liquid fuel and its annual production is greater than 100 billion liters, with an increase of $10 \%$ per year. More than $60 \%$ of ethanol is produced with fermentation technology using microorganisms [24]. 
From an engineering perspective, microbial strain selection is an important consideration. The best strain is one that suits and resists the characteristics of the fermenter environment, such as $\mathrm{pH}$, temperature, acidity, agitation, and biofuel toxicity.

Wild-type Escherichia coli produces ethanol under fermentative conditions by converting pyruvate to acetyl-CoA and formate through the enzyme pyruvate formate lyase, encoded by $p f l$ gene [15]. This process involves a two-step reaction: acetyl-CoA is converted to acetaldehyde, followed by ethanol synthesis. The overall reaction is catalyzed by a bifunctional aldehyde dehydrogenase (ADH), encoded by the adhE gene (Figure 1). Similarly, butanol is produced by the fermentative anaerobe, Clostridium acetobutylicums, through the acetone-butanol-ethanol (ABE) pathway [19]. The problem with wild-type strains is the low production titer. This is the main focus of most research into enhancing yields using metabolic engineering tools.

Pichia pastoris used for industrial production of chemicals was also engineered for butanol production [25]. The amino acid synthesis pathways of Pichia pastoris, specifically the endogenous L-valine biosynthesis pathway, was overexpressed to produce $2.22 \mathrm{~g} / \mathrm{L}$ of butanol from glucose as a carbon source [25]. Furthermore, using cheaper raw materials for the production of renewable biofuel could minimize the final cost. Glycerol is one of the cost effective byproducts of the biodiesel production industry. Engineered microbes could utilize glycerol as a carbon source. To obtain the phenotype, Saini et al. (2017) rewired the central metabolism of Escherichia coli to utilize glycerol as a carbon source, introduced a butanol synthesis pathway, and obtained a titer of $6.9 \mathrm{~g} / \mathrm{L}$ butanol from $20 \mathrm{~g} / \mathrm{L}$ glycerol (Table 1) [26]. This highest titer was obtained because of forcing glycolytic flux, enabling gluconeogenic pathway, improving the breakdown of glycerol and moderately suppressing tricarboxylic acid pathway [26]. To enhance production yield, Liew et al. (2017) introduced a novel pathway enzyme, aldehyde/alcohol ferredoxin reductase (AOR), to replace the native bifunctional aldehyde dehydrogenase in Clostridium autoethanogenum [9]. The strain was engineered using the allelic mutagenesis approach and as a result, the final strain produced ethanol at a titer of up to $180 \%$ $(0.28 \mathrm{~g} / \mathrm{L})$ from $\mathrm{CO}_{2}$ as a carbon source in batch fermentation experiments [9].

Furthermore, the yeast strains were found to be promising for butanol production. Pichia pastoris used industrial chemical production and has also been engineered for butanol production [25]. The endogenous L-valine biosynthesis pathway of P. pastoris was overexpressed to produce $2.22 \mathrm{~g} / \mathrm{L}$ of butanol from glucose as a carbon source [25]. Furthermore, using cheaper raw materials for renewable biofuel production could minimize the final cost. Glycerol, a byproduct of biodiesel production and other industrial processes, is a cost-effective raw material and engineered microbes could utilize it as a carbon source. Saini et al. (2017) rewired the central metabolism of Escherichia coli to utilize glycerol as the sole carbon source and introduced a butanol synthesis pathway that gives a production titer of $6.9 \mathrm{~g} / \mathrm{L}$ of butanol from $20 \mathrm{~g} / \mathrm{L}$ of glycerol (Table 1) [26]. This high titer was obtained by forcing glycolytic flux, enabling the gluconeogenic pathway, improving breakdown of glycerol, and moderately suppressing the tricarboxylic acid pathway [26]. The breakthrough report for butanol production was obtained using a Clostridium tyrobutyricum strain [27]. The complex regulatory pathway of butyrate production was manipulated by using the CRISPR-Cas system to delete cat1 (regulatory component) and to integrate adhE1 (alcohol producing) genes. The resultant strain achieved a record butanol titer of $26.2 \mathrm{~g} / \mathrm{L}$ in batch fermentation using $\mathrm{CO}_{2}$ as the carbon source (Table 1) [27].

\subsection{Alkanes Production in Bacteria}

High-energy renewable-fuel-like $n$-alkanes are direct replacements for petroleum fuel. These molecules range in chain length from $C_{8}$ to $C_{18}$. Chemically, $n$-alkanes are produced by the Fischer-Tropsch process, making them uneconomical. Biologically, $n$-alkanes are produced in Escherichia coli by modifying the lipid biosynthesis pathway and introducing aldehyde reductase (AAR) and aldehyde-deformylating oxygenase (ADO) from cyanobacteria [28]. Fatty acid synthesis plays a vital role in the production of $n$-alkanes. The prokaryotic fatty acid pathway is composed of individual components/enzymes. Acetyl-CoA enters the fatty acid pathway and a subsequent 
condensation reaction leads to the elongation of fatty acids. The alkane's production is directly related to fatty acid biosynthesis in bacteria. The fatty acid synthesis machinery of E. coli produces fatty acids from malonyl-CoA condensation. The first step in the fatty acid biosynthesis is carried out by acetyl-CoA carboxylase (ACC), a tetramer enzyme which produces malonyl-CoA from acetyl-CoA. The malonyl-CoA then transfers to acyl carrier protein (ACP) an elongation unit to get malonyl-ACP with the help of FabD, malonyl-CoA: ACP transcylase enzyme. The condensation cycle composes of four reactions catalyzed by FabH (3-oxooacyl-ACP synthase III), FabG (3-oxooacyl-ACP reductase), FabA/FabZ (enoyl-ACP synthase), and FabI (enoyl-ACP reductase), responsible for the production of 3-ketoacyl-ACP, 3-hydroxyacyl-ACP, enoyl-ACP, and acyl-ACP, respectively [16]. The fatty acids are then released from acyl carrier proteins with the help of thioesterases. Free fatty acids are then converted into fatty aldehydes and $n$-alkanes by AAR and ADO, respectively. The details of microbial biofuel production are shown in Table 1 and Figure 2.

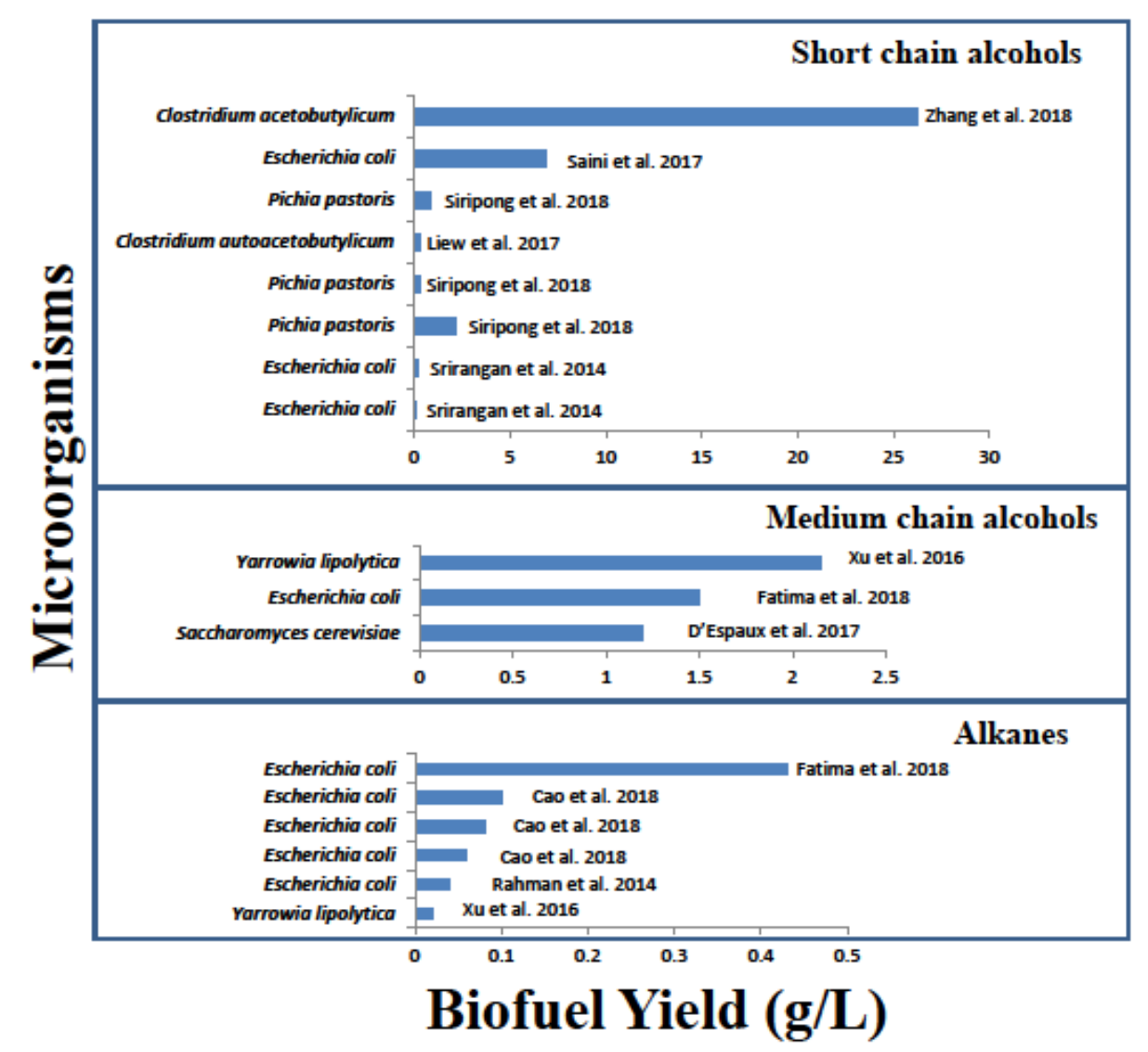

Figure 2. Recent studies on the production of short-chain alcohols, medium-chain alcohols and $n$-alkanes in microorganisms. The data represent batch fermentation experiments. For more detail, see Table 1.

\section{Comparative Analysis of Bio-Hydrocarbons Production in Bacteria}

Metabolic engineering plays a vital role in enhancing the production yield of bio-hydrocarbons. The ethanol produced in wild type E. coli with aldehyde dehydrogenase enzyme is far below the commercial threshold. To improve production yield, the genes of sleepy beauty mutase operon containing methyl malonyl CoA mutase, methyl malonyl CoA decarboxylase propinoyl CoA: Succinate transferase enzymes were expressed in E. coli that successfully produced 31 and $7 \mathrm{~g} / \mathrm{L}$ ethanol and propanol, respectively in a fed-batch fermentation (Tables 1 and 2). The pathway for the production of propanol using sleeping beauty mutase (Sbm) was different when compared to propanol production using the keto acid pathway [21]. The highest production of propanol by Sbm pathway may be due to anaerobic conditions as compared to the aerobic keto acid pathway [21,29]. 
The $\mathrm{C}_{4}$ alcohol (butanol) is considered better than ethanol in terms of hygroscopic properties and high energy densities [21]. The Clostridium acetobutylicum is a natural producer of butanol. The main problem in the wild type strain is butyrate production that lowers butanol synthesis. Zhang et al. (2018) speculated that by interrupting the butyrate synthesis genes, the butanol production may be enhanced. The spoA and cat 1 genes of butyrate synthesis were selectively deleted by using the CRISPR-Cas technology and as a result the highest titer of $26.2 \mathrm{~g} / \mathrm{L}$ butanol in batch fermentation was achieved (Tables 1 and 2). The breakthrough report for butanol production was obtained in Clostridium tyrobutyricum strain [27]. The complex regulatory pathway of butyrate production was manipulated with the CRISPR-Cas system by deletion of cat1 (regulatory component) and integration of adhE1 (alcohol producing) genes [27]. The resultant strain achieved record production of butanol up to $26.2 \mathrm{~g} / \mathrm{L}$ in a batch fermentation experiment using $\mathrm{CO}_{2}$ as a carbon source (Figure 2) [27].

The fatty alcohol's production is linked with fatty acid synthesis pathways [16]. The fermentative products such as lactate, acetate, pyruvate, and formate are also synthesized in fatty alcohols producing strains that lower the final production titer [8]. To overcome these problems, Fatima et al. (2018) developed a constraint-based modeling approach and identified the competing pathways, such as formate, lactate, and acetate synthesis. By blocking these pathways, 1.5 and $12.5 \mathrm{~g} / \mathrm{L}$ fatty alcohols were obtained in batch and fed-batch fermentation, respectively (Tables 1 and 2).

The alkane hydrocarbons are considered as a direct replacement for fossil petroleum [20]. The bio production of alkanes remains a major challenge because of slow acting aldehyde deformylating oxygenase, an alkane-producing enzymes (Figure 1) [28]. Currently, a number of efforts have been made to boost the alkane production but it is still far below the commercial threshold. The second problem is the toxicity of intermediate fatty aldehyde to the host cells. The toxicity of fatty aldehydes was overcome by applying DNA scaffolds to enzymes AAR and ADO and enhanced 8 -fold alkanes production $0.04 \mathrm{~g} / \mathrm{L}$ [28]. Cao et al. (2016) blocked the competing pathways such as endogenous reductases, and engineered the electron transfer system towards alkane-producing enzymes. The resultant strains produced 0.1 and $1.3 \mathrm{~g} / \mathrm{L}$ alkanes in a batch and fed-batch fermentation, respectively [30]. The details about current production yields and experimental conditions can be found in Tables 1 and 2.

Table 1. Biofuel production in engineered bacteria.

\begin{tabular}{|c|c|c|c|c|c|}
\hline Biofuel & Substrate & Microorganism & Metabolic Engineering & Yield (g/L) & References \\
\hline \multirow[b]{2}{*}{ Ethanol } & Glycerol & Escherichia coli & $\begin{array}{l}\text { Heterologous expression of sleeping beauty } \\
\text { mutase operon }\end{array}$ & $0.20^{\mathrm{a}}, 31^{\mathrm{b}}$ & [29] \\
\hline & $\mathrm{CO}_{2}$ & $\begin{array}{l}\text { Clostridium } \\
\text { autoacetobutylicum }\end{array}$ & $\begin{array}{c}\text { Allelic mutagenesis of aldehyde dehydrogenase } \\
\text { (adhE) and expression of aldehyde ferredoxin } \\
\text { reductase (AOR) }\end{array}$ & $0.28^{\mathrm{a}}$ & [9] \\
\hline Propanol & Glycerol & Escherichia coli & $\begin{array}{l}\text { Heterologous expression of sleeping beauty } \\
\text { mutase operon }\end{array}$ & $0.15^{\mathrm{a}}, 7^{\mathrm{b}}$ & [29] \\
\hline \multirow{5}{*}{ Butanol } & $\mathrm{CO}_{2}$ & $\begin{array}{l}\text { Clostridium } \\
\text { acetobutylicum }\end{array}$ & $\begin{array}{l}\text { Targeted deletion of sop } A \text { and cat } 1 \text { (butyrate } \\
\text { production) and integration of } a d h E \text { gene } \\
\text { by CRISPR-Cas } 9\end{array}$ & $26.2^{\mathrm{a}}$ & [27] \\
\hline & Glycerol & Escherichia coli & $\begin{array}{l}\text { Enhanced glycolytic flux, prevention of } \\
\text { glycerol breakdown }\end{array}$ & $6.9^{\mathrm{a}}$ & [26] \\
\hline & $\begin{array}{l}\text { 2-keto } \\
\text { isovalerate }\end{array}$ & Pichia pastoris & Expression of keto acid degradation pathway & $0.28^{\mathrm{a}}$ & [25] \\
\hline & \multirow[b]{2}{*}{ Glucose } & Pichia pastoris & $\begin{array}{l}\text { Overexpression of endogenous L-Valine } \\
\text { biosynthesis pathway }\end{array}$ & $0.89^{\mathrm{a}}$ & [25] \\
\hline & & Pichia pastoris & $\begin{array}{l}\text { Fine tuning of expression levels using } \\
\text { episomal plasmids }\end{array}$ & $2.22^{\mathrm{a}}$ & [25] \\
\hline
\end{tabular}


Table 1. Cont.

\begin{tabular}{|c|c|c|c|c|c|}
\hline Biofuel & Substrate & Microorganism & Metabolic Engineering & Yield $(\mathrm{g} / \mathrm{L})$ & References \\
\hline \multirow[t]{3}{*}{$\begin{array}{l}\text { Fatty } \\
\text { alcohols }\end{array}$} & Glucose & Escherichia coli & $\begin{array}{l}\text { In silico modelling of metabolic pathways for } \\
\text { alkane production to remove bottlenecks } \\
\text { identified in pentose phosphate pathway }\end{array}$ & $1.5^{\mathrm{a}}, 12.5^{\mathrm{b}}$ & [8] \\
\hline & Glucose & Yarrowia lipolytica & $\begin{array}{l}\text { Expression of alkane-producing pathway, } \\
\text { consisting of aldehyde reductase (AAR) and } \\
\text { aldehyde deformylating oxygenase (FAD) }\end{array}$ & $2.15^{\mathrm{a}}$ & [20] \\
\hline & Lignocellulose & $\begin{array}{l}\text { Saccharomyces } \\
\text { cerevisiae }\end{array}$ & $\begin{array}{l}\text { Expression of alkane-producing pathway } \\
\text { Bottlenecks were identified by flux balance } \\
\text { analysis and bacterial fatty aldehyde reductases } \\
\text { (FARs) were replaced with mouse FARs }\end{array}$ & $1.2^{\mathrm{a}}, 6^{\mathrm{b}}$ & [7] \\
\hline \multirow{6}{*}{ Alkanes } & \multirow{6}{*}{ Glucose } & Escherichia coli & $\begin{array}{l}\text { Heterologous expression of alkane-producing } \\
\text { pathway (AAR \& aldehyde-deformylating } \\
\text { oxygenase (ADO)) from cyanobacteria, with no } \\
\text { further modification }\end{array}$ & $0.06^{\mathrm{a}}$ & [30] \\
\hline & & Escherichia coli & $\begin{array}{l}\text { Expression of alkane-producing pathway } \\
\text { Deletion of } a d h E \text { (endogenous reductase) }\end{array}$ & $0.08^{\mathrm{a}}$ & [30] \\
\hline & & Escherichia coli & $\begin{array}{l}\text { Expression of alkane-producing pathway and } \\
\text { modification of electron transfer system }\end{array}$ & $0.1^{\mathrm{a}}, 1.3^{\mathrm{b}}$ & [30] \\
\hline & & Escherichia coli & $\begin{array}{l}\text { Expression of alkane-producing pathway and } \\
\text { DNA scaffolding of cyanobacterial AAR \& ADO }\end{array}$ & $0.04^{\mathrm{a}}$ & [28] \\
\hline & & Yarrowia lipolytica & $\begin{array}{l}\text { Expression of alkane-producing pathway } \\
\text { (FAR \& FAD), with no further modification }\end{array}$ & $0.02^{\mathrm{a}}$ & [20] \\
\hline & & Escherichia coli & $\begin{array}{l}\text { In silico modelling of metabolic pathways for } \\
\text { alkane production to help remove bottlenecks in } \\
\text { pentose phosphate pathway }\end{array}$ & $0.43^{\mathrm{a}}, 2.5^{\mathrm{b}}$ & [8] \\
\hline
\end{tabular}

Notes: ${ }^{\mathrm{a}}$ : batch fermentation; ${ }^{\mathrm{b}}$ : fed-batch fermentation.

Table 2. Comparison of experimental parameters of biofuel production in bacteria.

\begin{tabular}{|c|c|c|c|c|c|c|c|c|c|}
\hline \multirow[t]{2}{*}{ Biofuel } & \multirow[t]{2}{*}{ Microorganism } & \multicolumn{6}{|c|}{ Experimental Conditions } & \multirow[t]{2}{*}{ Yield (g/L) } & \multirow{2}{*}{$\begin{array}{c}\text { References } \\
{[29]}\end{array}$} \\
\hline & & Substrate & $\begin{array}{c}\text { Substrate } \\
\text { Concentration }\end{array}$ & $\mathrm{pH}$ & Temperature & $\begin{array}{l}\text { Cell Density } \\
\text { Initial-Final }\end{array}$ & $\begin{array}{l}\text { Reaction } \\
\text { Time }\end{array}$ & & \\
\hline \multirow[b]{2}{*}{ Ethanol } & Escherichia coli & Glycerol & $30 \mathrm{~g} / \mathrm{L}$ & 7.0 & $30^{\circ} \mathrm{C}$ & $0.4-1.8 \mathrm{~g} / \mathrm{DCW} / \mathrm{L}$ & $28 \mathrm{~h}$ & $0.20^{\mathrm{a}}, 31^{\mathrm{b}}$ & [9] \\
\hline & $\begin{array}{c}\text { Clostridium } \\
\text { autoacetobutylicum }\end{array}$ & $\mathrm{CO}_{2}$ & $50 \mathrm{kPa}$ & 5.8 & $37^{\circ} \mathrm{C}$ & $0.2-1.8 \mathrm{O}^{\mathrm{D}} \mathrm{D}_{600}$ & $30 \mathrm{~h}$ & $0.28^{\mathrm{a}}$ & [29] \\
\hline Propanol & Escherichia coli & Glycerol & $30 \mathrm{~g} / \mathrm{L}$ & 7.0 & $30^{\circ} \mathrm{C}$ & $1.8 \mathrm{~g} / \mathrm{DCW} / \mathrm{L}$ & $28 \mathrm{~h}$ & $0.15^{\mathrm{a}}, 7^{\mathrm{b}}$ & [27] \\
\hline \multirow{3}{*}{ Butanol } & Escherichia coli & Glycerol & $30 \mathrm{~g} / \mathrm{L}$ & 7.0 & $37^{\circ} \mathrm{C}$ & $0.2-7.0$ O.D $D_{550}$ & $40 \mathrm{~h}$ & $6.9^{\mathrm{a}}$ & [25] \\
\hline & Pichia pastoris & $\begin{array}{l}\text { 2-keto } \\
\text { isovalerate }\end{array}$ & $4 \mathrm{~g} / \mathrm{L}$ & - & $30^{\circ} \mathrm{C}$ & $0.05-12$ O.D 550 & $72 \mathrm{~h}$ & $0.28^{a}$ & [25] \\
\hline & Pichia pastoris & Glucose & $20 \mathrm{~g} / \mathrm{L}$ & - & $30^{\circ} \mathrm{C}$ & $0.05-1.2$ O.D $D_{550}$ & $72 \mathrm{~h}$ & $0.89^{\mathrm{a}}$ & [25] \\
\hline $\begin{array}{c}\text { Fatty } \\
\text { alcohols }\end{array}$ & $\begin{array}{c}\text { Saccharomyces } \\
\text { cerevisiae }\end{array}$ & Lignocellulose & $20 \mathrm{~g}$ biomass & 5.0 & $30^{\circ} \mathrm{C}$ & $1-25$ O.D 600 & $240 \mathrm{~h}$ & $1.2^{\mathrm{a}}, 6^{\mathrm{b}}$ & [30] \\
\hline \multirow{6}{*}{ Alkanes } & Escherichia coli & Glucose & $20 \mathrm{~g} / \mathrm{L}$ & 7.0 & $30^{\circ} \mathrm{C}$ & $0.5-4.0$ O.D $D_{600}$ & $50 \mathrm{~h}$ & $0.06^{\mathrm{a}}$ & [30] \\
\hline & Escherichia coli & Glucose & $20 \mathrm{~g} / \mathrm{L}$ & 7.0 & $30^{\circ} \mathrm{C}$ & $0.5-4.0$ O.D $D_{600}$ & $50 \mathrm{~h}$ & $0.08^{a}$ & [30] \\
\hline & Escherichia coli & Glycerol & $140 \mathrm{~g} / \mathrm{L}$ & 7.0 & $30^{\circ} \mathrm{C}$ & $0.5-140$ O. $\mathrm{D}_{600}$ & $50 \mathrm{~h}$ & $0.1^{\mathrm{a}}, 1.3^{\mathrm{b}}$ & [28] \\
\hline & Escherichia coli & Glucose & $20 \mathrm{~g} / \mathrm{L}$ & 7.0 & $30^{\circ} \mathrm{C}$ & $0.4-3.0$ O. $\mathrm{D}_{600}$ & $48 \mathrm{~h}$ & $0.04^{\mathrm{a}}$ & [20] \\
\hline & Yarrowia lipolytica & Glucose & $100 \mathrm{~g} / \mathrm{L}$ & 5.5 & $28^{\circ} \mathrm{C}$ & $1-80$ O.D 600 & $120 \mathrm{~h}$ & $0.02^{\mathrm{a}}$ & [8] \\
\hline & Escherichia coli & Glucose & $20 \mathrm{~g} / \mathrm{L}$ & 7.0 & $37^{\circ} \mathrm{C}$ & $0.02-102$ O.D $D_{550}$ & $72 \mathrm{~h}$ & $0.43^{\mathrm{a}}, 2.5^{\mathrm{b}}$ & [29] \\
\hline
\end{tabular}

Notes: ${ }^{\text {a }}$ batch fermentation; ${ }^{\mathrm{b}}$ : fed-batch fermentation. 


\section{Current Challenges in Improving Hydrocarbon Production}

\subsection{Promoters}

Promoters are important genetic elements responsible for the controlled expression of genes on a chromosome or plasmid [31,32]. In wild-type cells, promoters are well organized and controlled by repressors and inducible factors. From a bioengineering perspective, promoters are critical for balancing the metabolic flux of heterologous and/or engineered pathways by controlling the expression levels of individual genes. Therefore, choosing the correct promoter is an important step in engineering prokaryotic and eukaryotic cells. Uncontrolled gene expression in a heterologous host exerts a metabolic burden and results in the exhaustion of cellular biomolecules that are essential for cellular growth, leading to undesired physiological changes (Figure 3) [33]. Therefore, the promoter needs to be properly employed for smooth growth and productivity of the desired products. For example, when a target protein is toxic to the cell, a low-strength promoter is needed. If the expression of multiple genes is not optimized or if the catalytic activity of an enzyme is greater than the corresponding enzymes of the same metabolic pathway, it is recommended to balance the pathway with native/synthetic promoters to optimize flux towards the product. A wide range of promoters have been characterized and are available for research and academic purposes [34]. Historically, natural constitutive and inducible promoters have been used in this research. However, more recently, novel artificial promoters have been designed by modifying the -35 (TTGACA) and -10 (TATA) sequences. The expression patterns of these novel promoters are diverse [34]. Furthermore, two modes of transcription initiation have been reported. In the positive control mode, the interaction between regulatory proteins and their corresponding recognition sequences switches on transcription. In contrast, the negative control mode inhibits transcription initiation by the interaction of regulatory proteins with their regulatory regions. These synthetic promoters have been studied with the help of reporter genes coding for fluorescent proteins (GFP, RFP), luciferase, and galactosidase [35]. The promoters can be switched on/off using both chemical and physical stimuli. For instance, the Lac promoter is controlled by the LacI repressor and the IPTG inducer. The Tet promoter is controlled by the TetR repressor and the Tc inducer [36]. Therefore, selecting the appropriate promoter is critical for controlling gene expression levels and optimizing pathway flux. This can be achieved using either single-promoter-single-gene or single-promoter-multiple-gene expression systems. In addition, certain enzymes are required at different times of fermentation. Heat-inducible phage promoters and constitutive expression systems of Bacillus subtilis have proven promising for industrial and batch fermentation scales [37]. Currently, synthetic or artificial promoters are used in bacterial, yeast and mammalian cells. Basic questions about balancing pathway flux for biofuel production have been answered using synthetic promoters [38-40]. Another bottleneck in strain development for biofuel production is the combinatorial assembly of building blocks (promoters, genes, and terminators). These issues have mostly been solved using computational approaches, such as the DNA fragment compiler software, BioPartsBuilder [41].

\subsection{Gene Copy Number}

Gene expression level can also be regulated by controlling gene copy number (GCN). Changes in microbial GCN have been successful at balancing the flow of metabolites towards biofuels in engineered pathways. Enzymes in metabolic pathways have different catalytic turnover rates. Therefore, if their expression is not normalized according to their catalytic efficiencies, physiological disturbances such as toxicity and cell death can occur [33]. The strategies used to control the desired gene expression levels through GCN by selecting low-, medium-, and high-copy-number plasmids are discussed in the literature [42]. Gene expression levels can also be controlled by knocking down genes or integrating them into a chromosome, leading to a decrease or increase in $\mathrm{GCN}$, respectively [43]. Furthermore, the strategy to engineer high GCN plasmids has been successful in the fission yeast, Saccharomyces cerevisiae. In S. cerevisiae, CEN/ARS a centromere based plasmid has been engineered to obtain plasmid diversity with low, medium and high copy number versions [44]. For the development 
of Escherichia coli strains, plasmids with low, medium and high copy number per cell have been developed. Based on the ColE1 replicon, 15 to 20 plasmid copies per cell can be maintained. To obtain higher gene expression levels, $200+$ copies of the pMB1 replicon in the pUC plasmid have been used [45]. More recently, traditional gene cloning approaches are being replaced with novel self-cloning techniques, based on transcription activator-like effector nuclease (TALEN) in Pseudochoricystis ellipsoidea [46].
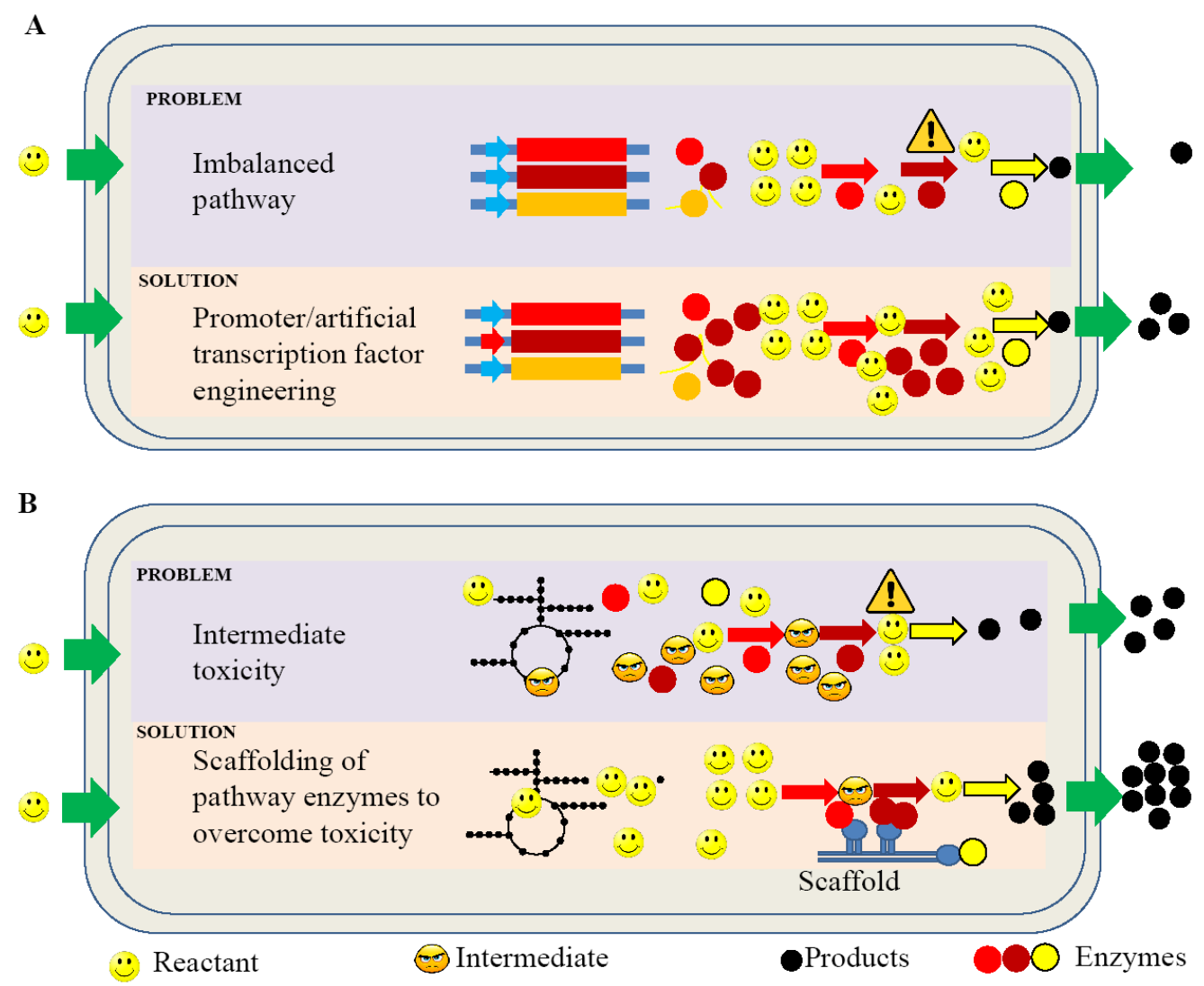

Figure 3. Graphical representation of improving bio-hydrocarbon production in bacteria. The figure shows challenges and possible solutions in transcription (A) and metabolite toxicity (B) in newly engineered strains.

\subsection{Artificial Transcription Factor (ATF) Engineering}

Artificial transcription factors (ATF) control genome-wide gene expression levels in engineered host cells to balance metabolic pathways (Figure 3). Transcription factors are composed of a DNA binding domain and an effector domain, both of which are required for regulating the expression of downstream genes. Specifically, the DNA binding domain is responsible for binding to the target regulatory site of a gene and the effector domain facilitates the initiation of downstream gene expression by RNA polymerase. Most ATFs are composed of zinc fingers (ZF) and sigma factors. ZF proteins bind specifically to DNA and function as regulatory factors. ATFs recognize specific DNA sequences, typically near the transcription start site of the target gene. Numerous methods have been developed for the construction of ATFs [47]. At present, ATFs are mainly used in industrial microorganisms to improve their tolerance to environmental stresses and to enhance the yield of chemicals and fuels. The ATF-based strain engineering approach has proven successful in improving tolerance to various environmental and physical stresses [48]. The T2 ATF has been shown to generate thermo tolerance and butanol tolerance phenotypes [48]. Furthermore, DNA microarray analysis of a T2 ATF strain showed up-regulation of the outer membrane protein gene, ompW and down-regulation of the marRAB operon. The exact function of OmpW is not known, but a previous publication has suggested that it 
has an important role during environmental stress and under physically varied conditions in industrial bioreactors [48]. Lee et al. (2011) engineered an ATF library by fusing ZFs with a cyclic adenosine mono phosphate receptor protein (CRP) and screened for butanol tolerance in E. coli [49]. Wild-type E. coli could not tolerate $1 \%(\mathrm{v} / \mathrm{v})$ butanol, but a butanol-tolerant strain with the ATF was able to tolerate $1.5 \%$ (v/v) butanol (Lee et al. 2011). Similarly, lignocellulosic properties of fungal species were studied for efficient degradation of plant cell walls. Ling et al. (2011) engineered a transcription factor from Saccharomyces cerevisiae to generate an $n$-alkanes-resistant phenotype by site-directed mutagenesis of the drug resistant transcription factors (PDR), PDR1P and PDR3P. Point mutations were generated (PDR1, F815S and PDR3, Y276H), which resulted in high tolerance to $\mathrm{C}_{10}$-alkanes (Ling et al. 2015). More recently, an acetic-acid-resistant phenotype was also generated using an ATF that successfully recognized novel genes responsible for the tolerance phenotype [50].

\subsection{Ribosome Engineering}

Ribosome engineering is also considered a useful tool for modulating gene expression levels. Ochi (2007) showed that the gene for ribosomal proteins, $r p s L$, could be engineered to dramatically turn on previously switched off genes [51]. Ribosomes, therefore, may be a useful tool for the production of microbes for biofuel production. The principle of ribosomal gene modification is to mimic the natural antibiotic resistance system developed by bacteria [52].

Ribosome engineering has proven to be a successful approach for the production of primary and secondary metabolites. Tanaka modified the rpsL gene in Propionibacterium shermanii, resulting in more than fivefold enhanced production of vitamin B12 [53]. The challenge with ribosome engineering is growth retardation of engineered strains, which may be due to the unavailability of free ribosomes for cellular growth. In addition, ribosome modification in Bacillus subtilis resulted in up to a $30 \%$ increase in amylase and protease production in the stationary phase [54]. Besides ribosome modification, the rapid availability of ribosomes for desired metabolic pathways has also proven to be beneficial for the production of antibiotics. This approach, which involves the introduction of a ribosome release factor, has been applied for improved antibiotic production in Streptomyces $[55,56]$.

\subsection{Transfer RNA Engineering}

Translation is the final step in the gene expression process. Translation requires energy and involves several steps: initiation, elongation and termination. The process is tightly regulated by a number of factors, such as the synthesis and degradation of the messenger RNA (mRNA), activation of transfer RNA (tRNA), and the coupling of tRNA with ribosomes. To obtain strains with high biofuel production, individual components involved in the translation process such as mRNA, tRNA, ribosomes, and various proteins required for translation can be modulated.

Biofuel-producing phenotypes have problems with fuel toxicity, as most proteins are denatured by the hydrophobic biofuel. This type of issue may be solved using tRNA engineering approaches. Recently, modified tRNAs were designed with different codon specificities to incorporate unnatural amino acids into proteins, resulting in the formation of novel proteins with altered or enhanced properties, such as resistance to toxic substances or enhanced catalytic efficiency [57].

Protein synthesis is based on the universal genetic code recognized by specific tRNAs. The term "tRNA engineering" refers to the chemical modification of tRNAs with unnatural amino acids that can then be incorporated into proteins [58]. Recently, in vivo modification of tRNA was demonstrated using a special aminoacyl tRNA synthetase to esterify unnatural amino acids to an engineered tRNA, i.e., tRNApyl $[59,60]$. More than 30 novel amino acids have been introduced into proteins using this technology [60]. Similarly, pyrrolysine, an unnatural amino acid analogue of lysine with a methyl-pyrroline moiety, was first identified in the active site of the enzyme monomethylamine methyltransferase from Methanosarcina barkeri [61]. Furthermore, it was found that pyrrolysine incorporation was due to tRNApyl containing the CUA anticodon, complementary to UAG bases. The uncharged tRNApyl is activated by pyrrolysyl-tRNA synthetase (PylRS). 
This technique can also be used to fine-tune certain enzymes to improve their function or pharmacological properties, e.g., in vivo incorporation of p-azido-L-phenylalanine for Phe170 or Phe281 in E. coli urate-oxidase [57]. Engineering proteins for functional metabolic pathways using this strategy may improve the productivity of biofuel in microbes. The described technologies also provide a path forward for biotech industries to modify their targets for improved activity [57].

Finally, advances in tRNA engineering broaden the field of phenotype engineering by allowing the incorporation of unnatural amino acids into structural and functional proteins of the cell. However, engineering aminoacyl tRNA synthetases and screening natural systems still present challenges for tRNA engineering.

\subsection{Cofactor Regeneration}

Cofactors such as NADH, NADPH, GTP, ATP, FAD, and FADH are important partners of catalytic reactions and enzymatic pathways. Therefore, the availability of these molecules is vital for a chemical reaction to proceed and improving their availability can enhance the efficiency of the pathway. The continuous supply of ATP in an engineered microbial host can boost the desired products [62]. The glutathione metabolic pathway requires ATP and blocking the ATP-consuming nlpD gene improves glutathione production [62]. Wang et al. (2013) showed up to a $90 \%$ production yield of 2,3-butanediol by improving NADH availability through overexpression of NADH-generating glucose and formate dehydrogenase enzymes [63]. Similar approaches have been applied in the yeast Pichia pastoris where blocking NADH-consuming pathways led to a boost in butanediol production [64].

\subsection{Scaffold System}

Nature has provided a sophisticated mechanism for enhancing pathway catalysis by using scaffolding enzymes. Many organisms have evolved multifunctional enzyme complexes such as fatty acid, polyketide, and alkaloid synthases for the biosynthesis of fatty acids polyketides, and alkaloids, respectively [65-67]. Applying this approach has led to the efficient production of artemisinin, an anti-malarial drug; $n$-alkanes; and biodiesel $[16,28,68-70]$. In our previous study, we demonstrated the potential of a DNA scaffold system for $n$-alkane production in E. coli. The critical enzymes of the $n$-alkane pathway, acyl-ACP reductase (AAR) and ADO, were linked to four zinc finger DNA-binding domains, capable of binding to a $12 \mathrm{bp}$ sequence on the DNA scaffold. This resulted in an eightfold increase in $n$-alkane production [16]. Design in synthetic biology is usually inspired by the spatial organization of enzymes observed in nature. This close approximation of enzymes to their desired distances and angles is made possible using modular scaffolds. The concept of scaffolding involves the use of small building blocks to allow the channeling of intermediates during a biochemical reaction (Figure 3). The advantage of such a system is that it prevents the diffusion of intermediates of sequential enzymatic reactions to nearby competing pathways, minimizing transit time and toxicity of certain intermediates $[16,28,70,71]$. Types of scaffolding include the immobilization, co-localization, compartmentalization, and spatial organization of enzymes on nucleic acids (DNA/RNA) and protein-protein scaffolding. During immobilization and co-localization, the enzymes of interest are targeted to the membrane via signal peptides as leading sequences. Enzyme scaffolds on nucleic acids are constructed by tagging nucleic acid binding domains onto the desired enzymes so that they land on the sequence of interest. Protein scaffolds can be constructed either as a fusion protein of two or more enzymes to form a large single multi-enzyme protein or by fusing an individual enzyme with protein binding domains that eventually lead to a complex of proteins or scaffolds. Coiled-coil proteins have been used to create this type of protein scaffold [72].

\section{Conclusions and Future Directions}

The global energy crisis and ever-increasing global warming may be addressed by decreasing reliance on fossil fuels. Alcohols and $n$-alkanes are currently the best replacements for petroleum fuel. The production yields of these biofuels are far below commercial level due to technical problems in 
strain optimization. In this review, gene expression optimization strategies such as the use of promoters, artificial transcription factors and gene copy number alterations were discussed. In addition, strategies for cofactor regeneration and scaffolding of pathway enzymes for metabolic pathway optimization were also discussed. Future tools must focus on rapid screening technologies for the selection of single microbial cells in real time to boost biofuel production.

Author Contributions: Z.R. conceived of this work. J.N. contributed to the manuscript text and figures. B.H.S. and S.C.K. supervised this work.

Funding: This work was supported by grants from the Higher Education Commission of Pakistan (Grant No. 5197/KPK/NRPU/R\&D/HEC/2016), the Intelligent Synthetic Biology Center of Global Frontier Project through the National Research Foundation funded by the Ministry of Science \& ICT of Korea, and the Research Initiative Program of KRIBB.

Acknowledgments: We are very thankful to Raham Sher, Department of Biotechnology, AWKUM for providing insights about global warming.

Conflicts of Interest: The authors have no conflicts of interest to declare.

\section{References}

1. Goldthau, A. The G20 must govern the shift to low-carbon energy. Nature 2017, 546, 203-205. [CrossRef] [PubMed]

2. Balch, J.K.; Nagy, R.C.; Archibald, S.; Bowman, D.M.; Moritz, M.A.; Roos, C.I.; Scott, A.C.; Williamson, G.J. Global combustion: The connection between fossil fuel and biomass burning emissions (1997-2010). Philos. Trans. R. Soc. Lond. B Biol. Sci. 2016, 371. [CrossRef] [PubMed]

3. Den, W.; Sharma, V.K.; Lee, M.; Nadadur, G.; Varma, R.S. Lignocellulosic biomass transformations via greener oxidative pretreatment processes: Access to energy and value-added chemicals. Front. Chem. 2018, 6, 141. [CrossRef] [PubMed]

4. Nejat, P.; Jomehzadeh, F.; Taheri, M.M.; Gohari, M.; Majid, M.Z.A. A global review of energy consumption, $\mathrm{CO}_{2}$ emissions and policy in the residential sector (with an overview of the top ten $\mathrm{CO}_{2}$ emitting countries). Renew. Sustain. Energy Rev. 2015, 43, 843-862. [CrossRef]

5. Shields-Menard, S.A.; Amirsadeghi, M.; French, W.T.; Boopathy, R. A review on microbial lipids as a potential biofuel. Bioresour. Technol. 2018, 259, 451-460. [CrossRef] [PubMed]

6. Dresselhaus, M.; Thomas, I. Alternative energy technologies. Nature 2001, 414, 332. [CrossRef] [PubMed]

7. d'Espaux, L.; Ghosh, A.; Runguphan, W.; Wehrs, M.; Xu, F.; Konzock, O.; Dev, I.; Nhan, M.; Gin, J.; Reider Apel, A.; et al. Engineering high-level production of fatty alcohols by Saccharomyces cerevisiae from lignocellulosic feedstocks. Metab. Eng. 2017, 42, 115-125. [CrossRef] [PubMed]

8. Fatma, Z.; Hartman, H.; Poolman, M.G.; Fell, D.A.; Srivastava, S.; Shakeel, T.; Yazdani, S.S. Model-assisted metabolic engineering of Escherichia coli for long chain alkane and alcohol production. Metab. Eng. 2018, 46, 1-12. [CrossRef] [PubMed]

9. Liew, F.; Henstra, A.M.; Kpke, M.; Winzer, K.; Simpson, S.D.; Minton, N.P. Metabolic engineering of Clostridium autoethanogenum for selective alcohol production. Metab. Eng. 2017, 40, 104-114. [CrossRef] [PubMed]

10. Demirbas, A. Biofuels sources, biofuel policy, biofuel economy and global biofuel projections. Energy Convers. Manag. 2008, 49, 2106-2116. [CrossRef]

11. Pandey, R.K.; Tewari, L. Mycotechnology for lignocellulosic bioethanol production: An emerging approach to sustainable environment. In Microbial Biotechnology in Environmental Monitoring and Cleanup; IGI Glob: Hershey, PA, USA, 2018; pp. 28-43. [CrossRef]

12. Babu, V.; Murthy, M. Butanol and pentanol: The promising biofuels for $\mathrm{CI}$ engines-A review. Renew. Sustain. Energy Rev. 2017, 78, 1068-1088.

13. No, S.-Y. Application of hydrotreated vegetable oil from triglyceride based biomass to CI engines-A review. Fuel 2014, 115, 88-96. [CrossRef]

14. Van Vliet, O.P.; Faaij, A.P.; Turkenburg, W.C. Fischer-Tropsch diesel production in a well-to-wheel perspective: A carbon, energy flow and cost analysis. Energy Convers. Manag. 2009, 50, 855-876. [CrossRef] 
15. Ohta, K.; Beall, D.S.; Mejia, J.P.; Shanmugam, K.T.; Ingram, L.O. Genetic improvement of Escherichia coli for ethanol production: Chromosomal integration of Zymomonas mobilis genes encoding pyruvate decarboxylase and alcohol dehydrogenase ii. Appl. Environ. Microbiol. 1991, 57, 893-900. [PubMed]

16. Rahman, Z.; Rashid, N.; Nawab, J.; Ilyas, M.; Sung, B.H.; Kim, S.C. Escherichia coli as a fatty acid and biodiesel factory: Current challenges and future directions. Environ. Sci. Pollut. Res. Int. 2016, 23, 12007-12018. [CrossRef] [PubMed]

17. Lu, X. A perspective: Photosynthetic production of fatty acid-based biofuels in genetically engineered Cyanobacteria. Biotechnol. Adv. 2010, 28, 742-746. [CrossRef] [PubMed]

18. Zhou, Y.J.; Buijs, N.A.; Siewers, V.; Nielsen, J. Fatty acid-derived biofuels and chemicals production in Saccharomyces cerevisiae. Front Bioeng. Biotechnol. 2014, 2, 32. [CrossRef] [PubMed]

19. Lin, Y.L.; Blaschek, H.P. Butanol production by a butanol-tolerant strain of Clostridium acetobutylicum in extruded corn broth. Appl. Environ. Microbiol. 1983, 45, 966-973. [PubMed]

20. Xu, P.; Qiao, K.; Ahn, W.S.; Stephanopoulos, G. Engineering Yarrowia lipolytica as a platform for synthesis of drop-in transportation fuels and oleochemicals. Proc. Natl. Acad. Sci. USA 2016, 113, 10848-10853. [CrossRef] [PubMed]

21. Atsumi, S.; Cann, A.F.; Connor, M.R.; Shen, C.R.; Smith, K.M.; Brynildsen, M.P.; Chou, K.J.; Hanai, T.; Liao, J.C. Metabolic engineering of Escherichia coli for 1-butanol production. Metab. Eng. 2008, 10, 305-311. [CrossRef] [PubMed]

22. Rutter, C.D.; Rao, C.V. Production of 1-decanol by metabolically engineered Yarrowia lipolytica. Metab. Eng. 2016, 38, 139-147. [CrossRef] [PubMed]

23. Elgaali, H.; Hamilton-Kemp, T.; Newman, M.; Collins, R.; Yu, K.; Archbold, D. Comparison of long-chain alcohols and other volatile compounds emitted from food-borne and related gram positive and gram negative bacteria. J. Basic Microbiol. 2002, 42, 373-380. [CrossRef]

24. Kohse-Hoinghaus, K.; Osswald, P.; Cool, T.A.; Kasper, T.; Hansen, N.; Qi, F.; Westbrook, C.K.; Westmoreland, P.R. Biofuel combustion chemistry: From ethanol to biodiesel. Angew. Chem. Int. Ed. Engl. 2010, 49, 3572-3597. [CrossRef] [PubMed]

25. Siripong, W.; Wolf, P.; Kusumoputri, T.P.; Downes, J.J.; Kocharin, K.; Tanapongpipat, S.; Runguphan, W. Metabolic engineering of Pichia pastoris for production of isobutanol and isobutyl acetate. Biotechnol. Biofuels. 2018, 11, 1. [CrossRef] [PubMed]

26. Saini, M.; Wang, Z.W.; Chiang, C.J.; Chao, Y.P. Metabolic engineering of Escherichia coli for production of n-butanol from crude glycerol. Biotechnol. Biofuels. 2017, 10, 173. [CrossRef] [PubMed]

27. Zhang, J.; Zong, W.; Hong, W.; Zhang, Z.T.; Wang, Y. Exploiting endogenous crispr-cas system for multiplex genome editing in Clostridium tyrobutyricum and engineer the strain for high-level butanol production. Metab. Eng. 2018, 47, 49-59. [CrossRef] [PubMed]

28. Rahman, Z.; Sung, B.H.; Yi, J.Y.; Bui le, M.; Lee, J.H.; Kim, S.C. Enhanced production of $n$-alkanes in Escherichia coli by spatial organization of biosynthetic pathway enzymes. J. Biotechnol. 2014, 192 Pt A, 187-191. [CrossRef]

29. Srirangan, K.; Liu, X.; Westbrook, A.; Akawi, L.; Pyne, M.E.; Moo-Young, M.; Chou, C.P. Biochemical, genetic, and metabolic engineering strategies to enhance coproduction of 1-propanol and ethanol in engineered Escherichia coli. Appl. Microbiol. Biotechnol. 2014, 98, 9499-9515. [CrossRef] [PubMed]

30. Cao, Y.X.; Xiao, W.H.; Zhang, J.L.; Xie, Z.X.; Ding, M.Z.; Yuan, Y.J. Heterologous biosynthesis and manipulation of alkanes in Escherichia coli. Metab. Eng. 2016, 38, 19-28. [CrossRef] [PubMed]

31. Garcia, H.G.; Brewster, R.C.; Phillips, R. Using synthetic biology to make cells tomorrow's test tubes. Integr. Biol. 2016, 8, 431-450. [CrossRef] [PubMed]

32. Smanski, M.J.; Zhou, H.; Claesen, J.; Shen, B.; Fischbach, M.A.; Voigt, C.A. Synthetic biology to access and expand nature's chemical diversity. Nat. Rev. Microbiol. 2016, 14, 135-149. [CrossRef] [PubMed]

33. Wu, G.; Yan, Q.; Jones, J.A.; Tang, Y.J.; Fong, S.S.; Koffas, M.A.G. Metabolic burden: Cornerstones in synthetic biology and metabolic engineering applications. Trends Biotechnol. 2016, 34, 652-664. [CrossRef] [PubMed]

34. Jensen, P.R.; Hammer, K. Artificial promoters for metabolic optimization. Biotechnol. Bioeng. 1998, 58, 191-195. [CrossRef]

35. Polli, F.; Meijrink, B.; Bovenberg, R.A.L.; Driessen, A.J.M. New promoters for strain engineering of Penicillium chrysogenum. Fungal. Genet. Biol. 2016, 89, 62-71. [CrossRef] [PubMed] 
36. Lutz, R.; Bujard, H. Independent and tight regulation of transcriptional units in Escherichia coli via the lacr/o, the tetr/o and arac/i1-i2 regulatory elements. Nucleic. Acids. Res. 1997, 25, 1203-1210. [CrossRef] [PubMed]

37. Ho, K.M.; Lim, B.L. Co-expression of a prophage system and a plasmid system in Bacillus subtilis. Protein Expr. Purif. 2003, 32, 293-301. [CrossRef] [PubMed]

38. Dehli, T.; Solem, C.; Jensen, P.R. Tunable promoters in synthetic and systems biology. Subcell. Biochem. 2012, 64, 181-201. [PubMed]

39. Song, Y.; Nikoloff, J.M.; Fu, G.; Chen, J.; Li, Q.; Xie, N.; Zheng, P.; Sun, J.; Zhang, D. Promoter screening from Bacillus subtilis in various conditions hunting for synthetic biology and industrial applications. PLoS ONE 2016, 11. [CrossRef] [PubMed]

40. Rudge, T.J.; Brown, J.R.; Federici, F.; Dalchau, N.; Phillips, A.; Ajioka, J.W.; Haseloff, J. Characterization of intrinsic properties of promoters. ACS Synth. Biol. 2016, 5, 89-98. [CrossRef] [PubMed]

41. Yang, K.; Stracquadanio, G.; Luo, J.; Boeke, J.D.; Bader, J.S. Biopartsbuilder: A synthetic biology tool for combinatorial assembly of biological parts. Bioinformatics 2016, 32, 937-939. [CrossRef] [PubMed]

42. Stewart, G.S.; Lubinsky-Mink, S.; Jackson, C.G.; Cassel, A.; Kuhn, J. Phg165: A PBR322 copy number derivative of puc8 for cloning and expression. Plasmid 1986, 15, 172-181. [CrossRef]

43. Atkinson, M.R.; Savageau, M.A.; Myers, J.T.; Ninfa, A.J. Development of genetic circuitry exhibiting toggle switch or oscillatory behavior in Escherichia coli. Cell 2003, 113, 597-607. [CrossRef]

44. Lian, J.; Jin, R.; Zhao, H. Construction of plasmids with tunable copy numbers in Saccharomyces cerevisiae and their applications in pathway optimization and multiplex genome integration. Biotechnol. Bioeng. 2016, 113, 2462-2473. [CrossRef] [PubMed]

45. Shizuya, H.; Birren, B.; Kim, U.J.; Mancino, V.; Slepak, T.; Tachiiri, Y.; Simon, M. Cloning and stable maintenance of 300-kilobase-pair fragments of human DNA in Escherichia coli using an f-factor-based vector. Proc. Natl. Acad. Sci. USA 1992, 89, 8794-8797. [CrossRef] [PubMed]

46. Kasai, Y.; Oshima, K.; Ikeda, F.; Abe, J.; Yoshimitsu, Y.; Harayama, S. Construction of a self-cloning system in the unicellular green alga Pseudochoricystis ellipsoidea. Biotechnol. Biofuels. 2015, 8, 94. [CrossRef] [PubMed]

47. Sera, T. Zinc-finger-based artificial transcription factors and their applications. Adv. Drug. Deliv. Rev. 2009, 61, 513-526. [CrossRef] [PubMed]

48. Lee, J.Y.; Sung, B.H.; Yu, B.J.; Lee, J.H.; Lee, S.H.; Kim, M.S.; Koob, M.D.; Kim, S.C. Phenotypic engineering by reprogramming gene transcription using novel artificial transcription factors in Escherichia coli. Nucleic. Acids. Res. 2008, 36. [CrossRef] [PubMed]

49. Lee, J.Y.; Yang, K.S.; Jang, S.A.; Sung, B.H.; Kim, S.C. Engineering butanol-tolerance in Escherichia coli with artificial transcription factor libraries. Biotechnol. Bioeng. 2011, 108, 742-749. [CrossRef] [PubMed]

50. Ma, C.; Wei, X.; Sun, C.; Zhang, F.; Xu, J.; Zhao, X.; Bai, F. Improvement of acetic acid tolerance of Saccharomyces cerevisiae using a zinc-finger-based artificial transcription factor and identification of novel genes involved in acetic acid tolerance. Appl. Microbiol. Biotechnol. 2015, 99, 2441-2449. [CrossRef] [PubMed]

51. Ochi, K. From microbial differentiation to ribosome engineering. Biosci. Biotechnol. Biochem. 2007, 71, 1373-1386. [CrossRef] [PubMed]

52. Santos, C.N.; Stephanopoulos, G. Combinatorial engineering of microbes for optimizing cellular phenotype. Curr. Opin. Chem. Biol. 2008, 12, 168-176. [CrossRef] [PubMed]

53. Tanaka, Y.; Kasahara, K.; Izawa, M.; Ochi, K. Applicability of ribosome engineering to vitamin B12 production by Propionibacterium shermanii. Biosci. Biotechnol. Biochem. 2017, 81, 1636-1641. [CrossRef] [PubMed]

54. Kurosawa, K.; Hosaka, T.; Tamehiro, N.; Inaoka, T.; Ochi, K. Improvement of alpha-amylase production by modulation of ribosomal component protein S12 in Bacillus subtilis 168. Appl. Environ. Microbiol. 2006, 72, 71-77. [CrossRef] [PubMed]

55. Hosaka, T.; Xu, J.; Ochi, K. Increased expression of ribosome recycling factor is responsible for the enhanced protein synthesis during the late growth phase in an antibiotic-overproducing Streptomyces coelicolor ribosomal rpsl mutant. Mol. Microbiol. 2006, 61, 883-897. [CrossRef] [PubMed]

56. Janosi, L.; Shimizu, I.; Kaji, A. Ribosome recycling factor (ribosome releasing factor) is essential for bacterial growth. Proc. Natl. Acad. Sci. USA 1994, 91, 4249-4253. [CrossRef] [PubMed]

57. Chen, M.; Cai, L.; Fang, Z.; Tian, H.; Gao, X.; Yao, W. Site-specific incorporation of unnatural amino acids into urate oxidase in Escherichia coli. Protein Sci. 2008, 17, 1827-1833. [CrossRef] [PubMed]

58. Rothschild, K.J.; Gite, S. Trna-mediated protein engineering. Curr. Opin. Biotechnol. 1999, 10, 64-70. [CrossRef] 
59. Gladyshev, V.N.; Jeang, K.T.; Stadtman, T.C. Selenocysteine, identified as the penultimate c-terminal residue in human t-cell thioredoxin reductase, corresponds to tga in the human placental gene. Proc. Natl. Acad. Sci. USA 1996, 93, 6146-6151. [CrossRef] [PubMed]

60. Yanagisawa, T.; Ishii, R.; Fukunaga, R.; Kobayashi, T.; Sakamoto, K.; Yokoyama, S. Multistep engineering of pyrrolysyl-trna synthetase to genetically encode $\mathrm{n}$ (epsilon)-(o-azidobenzyloxycarbonyl) lysine for site-specific protein modification. Chem. Biol. 2008, 15, 1187-1197. [CrossRef] [PubMed]

61. Burke, S.A.; Lo, S.L.; Krzycki, J.A. Clustered genes encoding the methyltransferases of methanogenesis from monomethylamine. J. Bacteriol. 1998, 180, 3432-3440. [PubMed]

62. Hara, K.Y.; Shimodate, N.; Hirokawa, Y.; Ito, M.; Baba, T.; Mori, H.; Mori, H. Glutathione production by efficient atp-regenerating Escherichia coli mutants. FEMS Microbiol. Lett. 2009, 297, 217-224. [CrossRef] [PubMed]

63. Wang, Y.; Li, L.; Ma, C.; Gao, C.; Tao, F.; Xu, P. Engineering of cofactor regeneration enhances (2S,3S)-2,3-butanediol production from diacetyl. Sci. Rep. 2013, 3, 2643. [CrossRef] [PubMed]

64. Geier, M.; Brandner, C.; Strohmeier, G.A.; Hall, M.; Hartner, F.S.; Glieder, A. Engineering Pichia pastoris for improved NADH regeneration: A novel chassis strain for whole-cell catalysis. Beilstein. J. Org. Chem. 2015, 11, 1741-1748. [CrossRef] [PubMed]

65. Ishikawa, M.; Tsuchiya, D.; Oyama, T.; Tsunaka, Y.; Morikawa, K. Structural basis for channelling mechanism of a fatty acid beta-oxidation multienzyme complex. EMBO J. 2004, 23, 2745-2754. [CrossRef] [PubMed]

66. Jorgensen, K.; Rasmussen, A.V.; Morant, M.; Nielsen, A.H.; Bjarnholt, N.; Zagrobelny, M.; Bak, S.; Moller, B.L. Metabolon formation and metabolic channeling in the biosynthesis of plant natural products. Curr. Opin. Plant. Biol. 2005, 8, 280-291. [CrossRef] [PubMed]

67. Pfeifer, B.A.; Khosla, C. Biosynthesis of polyketides in heterologous hosts. Microbiol. Mol. Biol. Rev. 2001, 65, 106-118. [CrossRef] [PubMed]

68. Akhtar, M.K.; Dandapani, H.; Thiel, K.; Jones, P.R. Microbial production of 1-octanol: A naturally excreted biofuel with diesel-like properties. Metab. Eng. Commun. 2015, 2, 1-5. [CrossRef] [PubMed]

69. Martin, V.J.; Pitera, D.J.; Withers, S.T.; Newman, J.D.; Keasling, J.D. Engineering a mevalonate pathway in Escherichia coli for production of terpenoids. Nat. Biotechnol. 2003, 21, 796-802. [CrossRef] [PubMed]

70. Yu, P.; Chen, X.; Li, P. Enhancing microbial production of biofuels by expanding microbial metabolic pathways. Biotechnol. Appl. Biochem. 2017, 64, 606-619. [CrossRef] [PubMed]

71. Jones, J.A.; Toparlak, O.D.; Koffas, M.A. Metabolic pathway balancing and its role in the production of biofuels and chemicals. Curr. Opin. Biotechnol. 2015, 33, 52-59. [CrossRef] [PubMed]

72. Peacock, A.F. Recent advances in designed coiled coils and helical bundles with inorganic prosthetic groups-from structural to functional applications. Curr. Opin. Chem. Biol. 2016, 31, 160-165. [CrossRef] [PubMed]

(C) 2018 by the authors. Licensee MDPI, Basel, Switzerland. This article is an open access article distributed under the terms and conditions of the Creative Commons Attribution (CC BY) license (http:/ / creativecommons.org/licenses/by/4.0/). 